JKTP Vol 3 No (2) Mei (2020): 149-157

DOI: $10.17977 /$ um038v3i22020p149

JKTP Jurnal Kajian Teknologi Pendidikan

http://journal2.um.ac.id/index.php/jktp/index

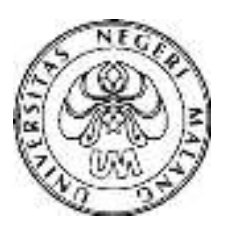

\title{
PENGEMBANGAN MEDIA VIDEO PEMBELAJARAN UNTUK PELATIHAN INSTALASI TENAGA LISTRIK
}

\author{
Gigih Latianda Febrianto, Sulton, Henry Praherdiono \\ Jurusan Teknologi Pendidikan, Fakultas Ilmu Pendidikan, Universitas Negeri Malang \\ JL.Semarang 5 Malang 65145 \\ Email:gigihlatianda025@gmail.com
}

\begin{tabular}{|c|c|}
\hline \multirow{2}{*}{ Article History } & Abstrak \\
\hline & \multirow{8}{*}{$\begin{array}{l}\text { Media pembelajaran pada dasarnya dapat digunakan dalam kegiatan } \\
\text { pembelajaran untuk semua tingkatan pendidikan, dengan memperhatikan } \\
\text { beberapa karakteristik siswa. Tujuan pengembangan ini adalah menghasilkan } \\
\text { produk media video pembelajaran untuk pelatihan instalasi tenaga listrik yang } \\
\text { valid dan efektif. Jenis pengembangan ini memakai metode pengembangan } \\
\text { model Sadiman. Pengembangan ini dilaksanakan di UPT Balai Latihan Kerja } \\
\text { Surabaya pada bulan Januari-April 2020. Subjek penelitian yaitu dosen } \\
\text { Universitas Negeri Malang dan } 16 \text { peserta pelatihan UPT Balai Latihan Kerja } \\
\text { Surabaya. Instrumen pengambilan data yaitu angket kevalidan untuk ahli } \\
\text { media, ahli materi, angket respons pengguna, dan instrumen pretes dan postes. } \\
\text { Hasil penelitian yaitu media video pembelajaran untuk pelatihan instalasi } \\
\text { tenaga listrik menunjukkan persentase validasi ahli materi sebesar } 89,2 \% \\
\text { (valid), ahli media } 96,9 \% \text { (valid), uji coba kelompok kecil sebesar } 87,2 \% \text {, } \\
\text { dengan hasil uji coba kelompok besar sebesar } 85 \% \text { (valid), dan persentase tes } \\
\text { hasil belajar sebesar } 86,5 \% \text { (efektif). } \\
\text { Abstract }\end{array}$} \\
\hline Received: $20-04-2020$ & \\
\hline Accepted: $30-04-2020$ & \\
\hline Published: $20-05-2020$ & \\
\hline & \\
\hline Keywords & \\
\hline \multirow[t]{4}{*}{$\begin{array}{l}\text { Media Pembelajaran, } \\
\text { Video Pembelajaran, } \\
\text { Instalasi Motor Listrik } 3 \\
\text { Fasa }\end{array}$} & \\
\hline & \\
\hline & Learning media basically can be used in learning activities for all levels of \\
\hline & $\begin{array}{l}\text { education, taking into account several characteristics of students. The purpose } \\
\text { of this development is to produce a learning video media product for training } \\
\text { electric power installations that is valid and effective. This type of development } \\
\text { uses the Sadiman model development method. This development was carried } \\
\text { out at the Surabaya Work Training Center UPT in January-April 2020. The } \\
\text { research subjects were lecturers at the State University of Malang and } 16 \\
\text { participants at the UPT Training Center at Surabaya. Data collection } \\
\text { instruments are validity questionnaires for media experts, material experts, } \\
\text { user response questionnaires, and pretest and posttest instruments. The results } \\
\text { of the study are instructional video media for electric power installation } \\
\text { training showing the percentage of material expert validation of } 89.2 \% \text { (valid), } \\
96.9 \% \text { of media expert (valid), small group trials of } 87.2 \% \text {, with group trial } \\
\text { results } 85 \% \text { (valid), and the percentage of learning outcomes tests is } 86.5 \% \\
\text { (effective). }\end{array}$ \\
\hline
\end{tabular}




\section{PENDAHULUAN}

Pada waktu ini dunia sudah mulai memasuki era dimana revolusi industri 4.0 (Aulbur, CJ, \& Bigghe, 2016). Revolusi industri menunjukan besar sekali manfaat yang dimiliki namun juga mempunyai tantangan yang wajib dihadapi kedepanya (Prasetyo \& Sutopo, 2018). Sebagian tantangan yang wajib dihadapi pada era revolusi industri 4.0 adalah munculnya resistensi perubahan demografi, perubahan aspek sosial (Prasetyo \& Sutopo, 2018), dan menimbulkan persaingan dunia kerja semakin ketat (Mardiah, 2019), sehingga setiap individu dituntut untuk memiliki kompetensi dalam meningkatkan sumber daya manusia (Azmy, 2015) karena beberapa fungsi sumber daya manusia akan digantikan dengan artificial intelligence.

Unit Pelaksanaan Teknis (UPT) Balai Latihan Kerja Surabaya sebagai salah satu lembaga pelatihan milik pemerintah daerah yang bergerak dalam bidang teknologi. Oleh sebab itu UPT Balai Latihan Kerja Surabaya dijadikan motor penggerak dalam memberikan pelatihan kepada peserta pelatihan untuk mendapatkan bekal pendidikan dan keterampilan. Peserta pelatihan dibekali dengan berbagai ilmu yang diperoleh dari lembaga pelatihan teknik listrik sesuai dengan divisi yang ada seperti divisi instalasi tenaga listrik, teknik pendingin, instalasi penerangan dan divisi embeded system, merupakan salah satu bidang ilmu (mata pelatihan).

Salah satu materi yang paling sering diterapkan pada kehidupan sehari-hari, baik untuk rumah tangga, transportasi \& industri adalah instalasi motor listrik 3 fasa (Ardiansyah, Nrartha, \& Sukmadana, 2017). Motor listrik 3 fasa mempunyai konstruksi yang kokoh, sederhana, harganya murah, juga perawatannya yang dikategorikan lebih mudah. Pembelajaran instalasi motor listrik 3 fasa membutuhkan metode yang tepat. Hal ini bertujuan agar capaian belajar dapat dicapai secara menyeluruh. Untuk mencapai hal tersebut para pengajar perlu memodifikasi kegiatan pembelajaran. Salah satu yang dapat dimodifikasi adalah ketersediaan media dan sumber belajar pendukung.

Media pembelajaran berpengaruh untuk menentukan efektiv dan efisien pencapaian proses pembelajaran yang maksimal. Terdapat berbagai macam jenis media, tetapi penggunaannya banyak sekaligus justru akan membuat siswa kebingungan. Oleh karena itu seorang pengajar wajib mengenal berbagai media beserta karakteristiknya dan menetapkan media yang paling cocok untuk tujuan pembelajarannya.

Media pembelajaran pada dasarnya dapat digunakan dalam kegiatan pembelajaran untuk semua tingkatan pendidikan dengan memperhatikan beberapa karakteristik siswa. Media pembelajaran dapat berupa visual (Nugrahani \& Rupa, 2007), audio (Mustika, 2015), dan audio visual (Purnomo, Yutmini, \& Anitah, 2014). Media yang digunakan dalam pengembangan ini berupa video pembelajaran, media ini merupakan media audio visual. Sadiman (2011), menjelaskan bahwa media video berupa audio visual yang menampilkan gerak. Video juga media dan alat bantu mengajar yang berisi pesan-pesan pembelajaran. Media video bisa mengasah siswa untuk berpikir konkret, logis, lebih nyata, dan menciptakan kegiatan pembelajaran yang aktif, kreatif, dan berkesan (Hardianti \& Asri, 2017). Media video mempunyai kelebihan supaya mempermudah siswa dalam mengimplementasikan materi yang ada melalui video pembelajaran tersebut (Johari, Hasan, \& Rakhman, 2016). Ketersediaan media pembelajaran yang baik dapat memberikan dampak linier pada kegiatan dan strategi pembelajaran yang digunakan (Jatmika, 2005).

Allen (1975) mengemukakan bahwa media video mempunyai kemampuan yang tinggi dalam mempengaruhi belajar konsep, prinsip dan aturan. Sedangkan video mempunyai kemampuan yang rendah dalam membelajarkan keterampilan, persepsi dan gerak. Kemampuan menengah dimiliki oleh video pada saat membelajarkan informasi faktual, pengenalan visual, prosedur, sikap, opini, dan motivasi.

Pada usia remaja mata pelatihan yang berbasis $80 \%$ praktik dan $20 \%$ teori pada dasarnya memiliki tingkat kesulitan yang tinggi dalam mempelajarinya. Pada mata pelatihan instalasi motor listrik 3 fasa, materi-materi yang dipelajari berhubungan dengan sistem perkabelan membuat peserta pelatihan kesulitan dalam memahami pelajaran teori dengan adanya $20 \%$ materi teori. Jadi pengajar harus mengelola jam pelatihan yang dimiliki, agar seluruh materi teori dapat tersampaikan kepada peserta pelatihan dengan baik. 
Berkaitan dalam penelitian yang dilakukan. Terdapat sejumlah pengkajian signifikan \& telah dilaksanakan oleh (Sanjaya, Adiarta, \& Santiyadnya, 2018) dengan judul "Pengembangan media pembelajaran pemasangan instalasi listrik dan video tutorial instalasi listrik dalam mata kuliah dasardasar instalasi di program studi pendidikan teknik elektro UNDIKSHA". Dalam penelitian itu disimpulkan bahwa penggunaan media pembelajaran pemasangan instalasi listrik dapat digunakan untuk membantu proses pembelajaran, dan media ini layak dipergunakan sebagai media bantu pembelajaran, dari mahasiswa sendiri mendapatkan respons yang bagus pada mata kuliah dasar-dasar instalasi di Program Studi Pendidikan Teknik Elektro Undiksha.

Pola pembelajaran yang bermutu seharusnya mampu membantu para siswa mengembangkan diri secara optimal, serta sanggup mencapai tujuan pembelajaran yang dicapai. Proses pembelajaran diharapkan supaya berpusat kepada siswa dan siswa yang harus belajar (student centered) (Corley, 2012; Hesson \& Shad, 2007; Neill \& Mcmahon, 2005). Menurut aliran konstruktivis, mengajar bukanlah aktivitas memindahkan pengetahuan berdasarkam pengajar ke siswa, melainkan suatu aktivitas yang memungkinkan siswa membentuk sendiri pengetahuannya (Suparno, 1997). Menurut prinsip ini, seseorang pengajar berperan menjadi mediator dan fasilitator yang membantu agar proses belajar berjalan baik. Proses pembelajaran perlu diupayakan \& dikembangkan tidak semata-mata berorientasi pada hasil belajar yang dapat diamati, tetapi perlu penekanan pada "learning how to learn" (Nur, 2005) Menurut Arends (1997), menjelaskan bahwa pengajaran yang baik meliputi mengajar siswa tentang bagaimana belajar, menggunakan ingatan, bagaimana berpikir, dan bagaimana memotivasi diri sendiri.

Berdasarkan observasi yang dilakukan peneliti di UPT Balai Latihan Kerja Surabaya, telah menerapkan pembelajaran di kelas berdasarkan Standard Operating Procedure (SOP), namun dalam pelaksanaan pembelajaran di kelas dirasa kurang maksimal dalam memberikan materi teori instalasi motor listrik 3 fasa. Ada beberapa faktor penghambat yang membuat peserta kurang maksimal: (1) materi pada media cetak (buku modul) yang padat, berpengaruh pada tingkat visualisasi atau pemaknaan peserta pelatihan terhadap materi, (2) pengajar instalasi motor listrik 3 fasa memiliki satu bulan untuk menyampaikan materi secara keseluruhan $80 \%$ praktik dan $20 \%$ teori. Jadi pengajar harus mengelola jam pelatihan yang dimiliki, agar seluruh materi teori dapat tersampaikan kepada peserta pelatihan dengan baik.

Sehubungan dengan permasalahan ini, ada penelitian yang sejenis yang mempunyai permasalahan yang sama. Menurut pengkajian yang sudah dilakukan (Tenny Widya, 2011) dengan judul "Pengembangan media video pembelajaran pertempuran di Surabaya untuk siswa kelas IX SMP Negeri 1 Kalitidu Bojonegoro". Dalam penelitian itu disimpulkan bahwa keterbatasan ruang \& waktu dimiliki pengajar mata pelajaran IPS Sejarah menjadikan pengajar kurang maksimal memberikan materi keseluruhan secara mendetail, sebagai dampak pengetahuan materi yang di punyai siswa kurang maksimal. Pengetahuan materi yang kurang disukai siswa akhirnya berdampak kepada hasil belajar siswa yang mementingkan kriteria ketuntasan minimal.

Video pembelajaran diharapkan hadir pada saat menghilangkan kejenuhan pada waktu pembelajaran, agar peserta didik fokus dalam pembelajaran. Media pembelajaran berbentuk video ini dapat meningkatkan hasil belajar kognitif siswa (Kurniawan, Kuswandi, \& Husna, 2018). Sejalan dengan penelitian (Woottipong, 2014) media video menjadi berpengaruh terhadap hasil belajar dan keterampilan siswa yang di teliti. Menggunakan media video mempunyai hasil belajar lebih tinggi daripada tidak memakai media video (Nur, 2005).

Usaha yang bisa dilakukan agar mengatasi permasalahan yang ada dengan mengembangkan media pembelajaran berupa video sangat dibutuhkan dalam membantu kegiatan pembelajaran dan menunjang proses pembelajaran peserta pelatihan, media ini dipergunakan untuk mempermudah pengajar dalam proses belajar secara bebas, sehingga peserta pelatihan masih bisa belajar kapanpun dan dimanapun. Berdasarkan observasi di UPT Balai Latihan Kerja Surabaya, pengembang berusaha menciptakan pembelajaran yang inovatif mengikuti perkembangan teknologi, sehingga meningkatkan pemahaman peserta pelatihan dalam memahami materi teori instalasi motor listrik 3 fasa, dan sesuai dengan ulasan di atas bahwa terbatasnya waktu menjadi masalah dalam proses pembelajaran instalasi motor listrik 3 fasa yang memerlukan waktu yang cukup banyak dalam proses pembelajaran dan praktik disamping 
itu materi pada media cetak (buku modul) yang padat, berpengaruh pada tingkat visualisasi atau pemaknaan peserta pelatihan terhadap pemahaman materi.

\section{METODE}

Model pengembangan yang dipergunakan sebagai acuan pada pengembangan video pembelajaran materi instalasi motor listrik 3 fasa merupakan contoh model pengembangan program media instruksional menurut Sadiman (2011). Model tersebut dipilih karena berfokus pada pengembangan suatu program atau produk media untuk kebutuhan pembelajaran. Di bawah ini merupakan gambaran alur tahap model pengembangan.

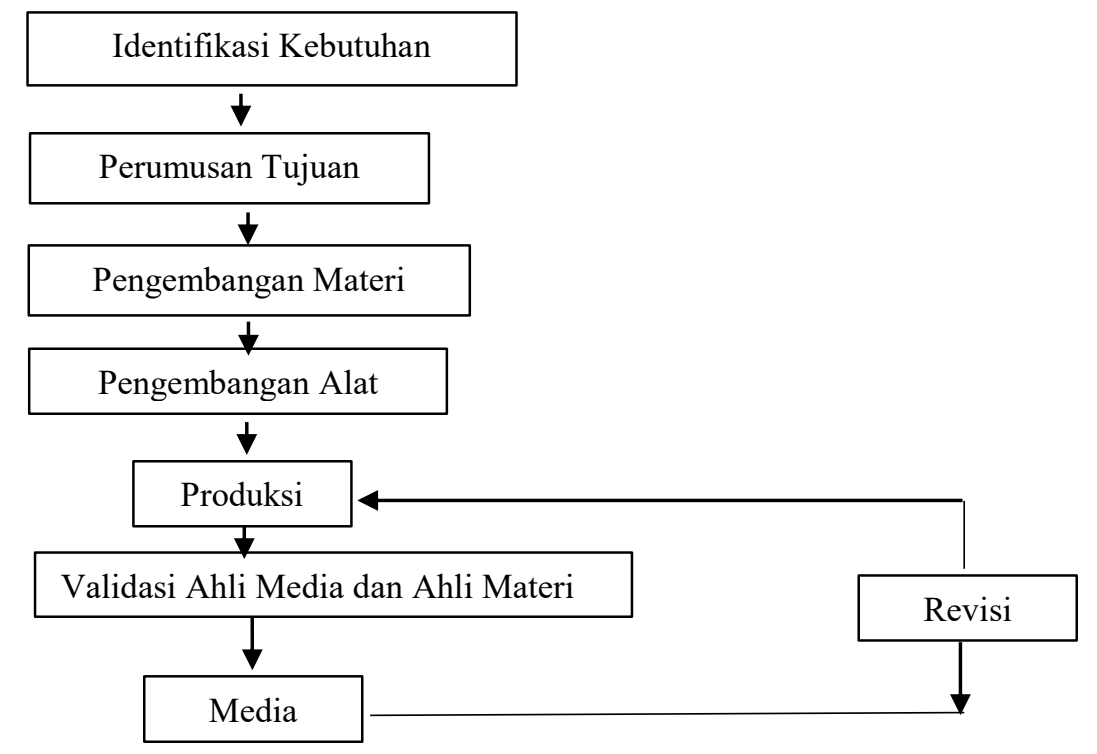

Gambar 1. Bagan Prosedur Pengembangan Media Instruksional menurut

Model pengembangan Sadiman (2011) memiliki 9 tahap pengembangan, yaitu: (1) menganalisis kebutuhan dan karakteristik siswa; (2) merumuskan tujuan instruksional; (3) merumuskan materi secara terperinci; (4) mengembangkan alat pengukur keberhasilan; (5) menulis naskah media; (6) produksi; (7) mengadakan tes/uji coba; (8) revisi; (9) produk siap dimanfaatkan.

Tahap uji coba video pembelajaran melibatkan subjek penelitian yang terdiri dari ahli media, ahli materi, dan peserta pelatihan. Uji coba validasi produk, video pembelajaran ini divalidasikan ke ahli media dan ahli materi. Setelah media dinyatakan valid, produk diujicobakan ke lapangan secara langsung untuk mendapatkan penilaian dan respons dari peserta pelatihan. Uji coba lapangan dilaksanakan 08 April 2020 secara online. Subjek uji coba lapangan adalah peserta pelatihan instalasi tenaga listrik UPT Balai Latihan Kerja Surabaya sebanyak 16 peserta pelatihan, yang terdiri dari 14 peserta pelatihan laki-laki dan 2 peserta pelatihan perempuan.

Teknik akumulasi data pada penelitian ini memakai instrumen berbentuk angket penilaian. Angket yang digunakan bertujuan untuk memperoleh data penilaian dan respons dari ahli media, ahli materi, dan peserta pelatihan sebagai bahan evaluasi pada video pembelajaran yang dikembangkan. Teknik analisis data yang digunakan dalam menganalisis data dengan temuan penilaian berdasarkan subjek uji coba pada pengembangan ini merupakan analisis kuantitatif dan kualitatif. Teknik penjabaran data kuantitatif menggunakan teknik persentase (Arikunto, 2002). Persentase yang diperoleh kemudian dikonversikan menjadi data kualitatif, untuk mengetahui kategori tingkat kevalidan dari video pembelajaran yang dikembangkan. Adapun indikator aspek instrumen untuk masing-masing responden sebagai berikut.

Instrumen penelitian berisi tentang aspek-aspek yang berhubungan dengan video pembelajaran, meliputi segi fungsi \& manfaat, media visual, media audio, tipografi, bahasa, dan 
pemrograman media. Sedangkan aspek yang diukur dalam instrumen validasi ahli materi adalah identitas mata pelajaran, rumusan indikator dan tujuan belajar, pemilihan materi, bahasa serta kualitas instruksional. Sedangkan aspek yang diukur dalam instrumen ahli media adalah antar muka produk video pembelajaran, konten, dan prinsip video pembelajaran. Instrumen untuk responden/peserta pelatihan memiliki tiga aspek yang diukur dalam instrumen yaitu tampilan, penyajian materi, dan juga manfaat produk video pembelajaran. Instrumen dalam penelitian ini menggunakan skala Likert dengan lima alternatif.

Data analisis yang digunakan pada hasil penilaian berdasarkan subjek uji coba pada pengembangan ini adalah teknik analisis kuantitatif dan kualitatif. Teknik analisis data kuantitatif menggunakan teknik persentase (Arikunto, 2002). Dari persentase yang diperoleh kemudian dikonversikan menjadi data kualitatif, Adapun kategori kevalidan data adalah sebagai berikut:

Tabel 1. Kategori Kevalidan

\begin{tabular}{cccc}
\hline Kategori & Persentase & Kriteria & Kualifikasi \\
\hline A & $85-100$ & Valid & Layak \\
B & $70-84$ & Cukup Valid & Cukup Layak \\
C & $55-69$ & Kurang Valid & Kurang Layak \\
D & Dibawah 55 & Tidak Valid & Tidak Layak \\
\hline
\end{tabular}

Sumber: (Arikunto, 2002)

Keterangan:

1. Apabila hasil analisis memperoleh kategori A (85-100) maka media tersebut termasuk kriteria valid, dan layak digunakan untuk proses pembelajaran

2. Apabila hasil analisis memperoleh kategori B (70-84) maka media tersebut termasuk kriteria cukup valid, dan layak digunakan dalam proses pembelajaran.

3. Apabila hasil analisis memperoleh kategori C (55-69) maka media tersebut termasuk kriteria kurang valid, dan multimedia pembelajaran harus direvisi. Artinya tidak layak digunakan untuk proses pembelajaran.

4. Apabila hasil analisis memperoleh kategori D (dibawah 55) maka media tersebut termasuk kriteria tidak valid, dan media pembelajaran harus diganti.

\section{HASIL}

Tabel 2. Hasil Validasi Ahli

\begin{tabular}{ccc}
\hline No & Validator & Persentase \\
\hline 1 & Ahli Materi & $89,2 \%$ \\
2 & Ahli Media & $96,9 \%$ \\
\hline
\end{tabular}

Berdasarkan pengolahan data ahli materi yang tersedia pada Tabel 2, secara keseluruhan dapat diperoleh hasil 89,2\% (valid) dan dapat diteruskan ke tahap selanjutnya. Hasil validasi oleh ahli media yang tersedia pada Tabel 2, secara keseluruhan dapat diperoleh hasil 96,9\%. Berdasarkan hasil tersebut, video pembelajaran yang telah dikembangkan valid. 
Tabel 3. Hasil Uji Kelompok Kecil, Kelompok Besar, dan Tes Hasil Belajar

\begin{tabular}{ccc}
\hline No & Uji Coba & Persentase \\
\hline 1 & Uji Coba Kelompok Kecil & $87,2 \%$ \\
2 & Uji Coba Kelompok Besar & $85 \%$ \\
3 & Tes Hasil Belajar & $86,5 \%$
\end{tabular}

Uji coba produk dilakukan pada 16 peserta pelatihan instalasi tenaga listrik materi instalasi motor listrik 3 fasa. Berdasarkan uji coba kelompok kecil secara keseluruhan memperoleh hasil 87,2\%. Dari hasil uji coba kelompok kecil, video pembelajaran yang telah dikembangkan valid atau layak dan media siap di uji coba dalam pembelajaran di kelas. Setelah melakukan ujicoba kelompok besar/uji coba lapangan secara keseluruhan memperoleh hasil 85\%. Dari uji coba kelompok besar/uji coba lapangan, video pembelajaran yang telah dikembangkan Valid atau layak dan siap digunakana untuk pembelajaran di dalam kelas.

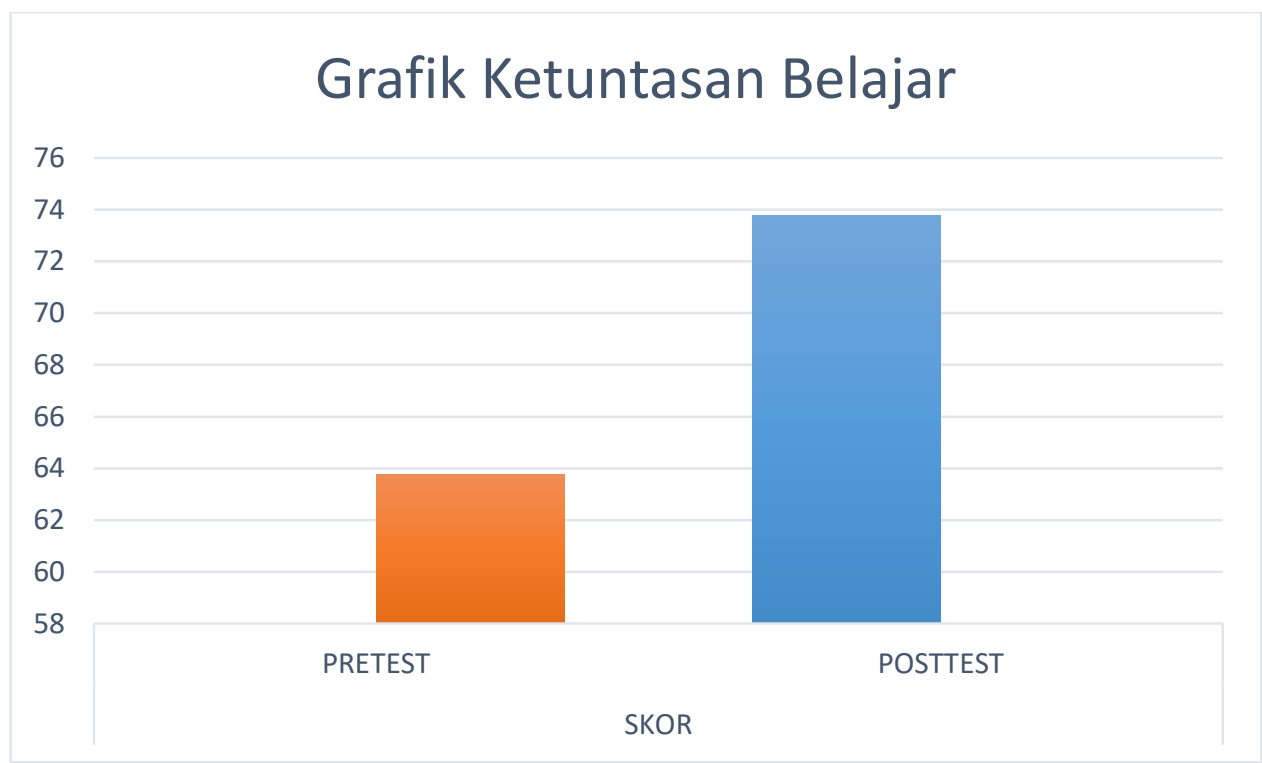

Gambar 2. Perbandingan skor Pre-Test dan Post-test

Berdasarkan gambar 2 dapat dilihat bahwa pada tahap post-test rata-rata skor hasil belajar peserta pelatihan mengalami peningkatan dari 63,75 menjadi 73,75. Adapun skor tertinggi yang diraih peserta pelatihan sebesar 90 sedangkan skor terendah sebesar 50. Hasil tersebut menunjukkan bawa nilai tertiggi yang diraih oleh peserta pelatihan sudah berada pada kategori sangat baik, sedangkan nilai terendah yang didapatkan peserta pelatihan berada pada kategori kurang. Nilai rerata yang didapatkan oleh peserta pelatihan adalah 73.75 yang berada pada kategori cukup.

Dari berbagai uji yang telah dilakukan, pengembangan media video pembelajaran mendapat cukup banyak respons positif. Hasil pengembangan video pembelajaran ini telah divalidasi oleh ahli media, ahli materi, dan responden (peserta pelatihan). Media tersebut dinyatakan valid atau layak untuk digunakan sebagai video pembelajaran instalasi motor listrik 3 fasa. Hal ini dibuktikan dengan hasil perhitungan statistik yaitu dari ahli materi didapatkan skor persentase sebesar $89,2 \%$, ahli media sebesar $96.9 \%$, dari uji coba kelompok kecil didapat skor persentase $87,2 \%$ dan dari uji coba kelompok besar dengan presentase $85 \%$. Hal ini menunjukkan bahwa video pembelajaran ini valid dan layak untuk digunakan sebagai media pembelajaran.

\section{PEMBAHASAN}

Media video tergolong bagian dari jenis-jenis media pembelajaran. Salah satu yang mampu dimanfaatkan oleh guru menjadi media bantu pembelajaran, jenis media berbasis audio-visual (Hartanti, Djatmika, \& Setyosari, 2017). Media video mempunyai banyak kelebihan dalam meringkas isi materi pembelajaran. Pemilihan media pembelajaran yang tidak menarik menjadikan siswa bosan dan tidak 
termotivasi (Haryani, 2018). Sebagai pengantar informasi yang efektif media akan berperan optimal sebagai penunjang pembelajaran (Hadi, 2017). Dalam waktu penyajian materi memakai media video, proses pembelajaran akan menjadi lebih menarik \& bisa mendorong hasil belajar terus membaik.

Dari berbagai uji yang telah dilakukan media video mendapat cukup banyak respons positif. Hasil pengembangan video pembelajaran ini telah divalidasi oleh ahli media, ahli materi, dan responden (peserta pelatihan). Media video dinyatakan valid atau layak dipergunakan sebagai media pembelajaran instalasi motor listrik 3 fasa. Pada hal ini dibuktikan dengan hasil yang sudah diujicobakan dari ahli materi didapatkan skor persentase sebesar $89,2 \%$, ahli media sebesar $96.9 \%$, dari uji coba kelompok kecil didapat skor persentase $87,2 \%$ dan dari uji coba kelompok besar dengan persentase $85 \%$. Berdasarkan berbagai uji yang telah dilakukan menunjukkan bahwa video pembelajaran ini valid dan layak untuk digunakan sebagai media pembelajaran.

Berdasarkan tanggapan dari ahli media, ahli materi, dan responden maka pada produk video pembelajaran ini dilakukan perbaikan atau revisi pada bagian berikut: kualitas volume suara host/narator/penyaji, sebaiknya menggunakan clip mic, sehingga suara terekam secara jelas/maksimal. Tetapi karena recording sudah selesai, sebaiknya sesi penyajian host dilengkapi display teks/kalimat isi sajian suara host tersebut. Hal lain yang bisa dioptimalkan adalah zoom in/extreme zooming dalam memvisualkan komponen-komponen yang kecil pada peragaan kelistrikan. Oleh karena itu pengembang melakukan perbaikan berdasarkan komentar dan saran dari para ahli media, ahli materi dan responden/peserta pelatihan. Setelah dilakukan tahap revisi video pembelajaran instalasi motor listrik 3 fasa untuk pelatihan instalasi tenaga listrik video layak untuk digunakan dalam kegiatan pembelajaran. Media video pembelajaran bisa digunakan dalam alternatif media pembelajaran di kelas.

Hasil tes belajar peserta pelatihan menunjukkan angka ketuntasan sebesar $86,6 \%$ yang artinya peserta pelatihan dapat memahami materi dengan mudah. Berdasarkan penelitian yang pernah dilakukan oleh (Nugroho, 2015; Pradipta, Sutarto, \& Ghani, 2016) yang menunjukkan adanya dampak positif yang signifikan terhadap penggunaan media pembelajaran berupa video. Video pembelajaran dapat meningkatkan pemahaman konsep materi instalasi listrik peserta pelatihan. Sejalan dengan pernyataan Pradipta et al., (2016) hasil wawancara yang dilakukan menunjukkan, memudahkan siswa untuk memahami dan mengingat materi dalam pembelajaran. Melalui video, suasana belajaran bertambah menyenangkan dan tidak membosankan (Hardianti \& Asri, 2017), karena terdapat unsur visual dan audio yang terakomodasi sehingga meningkatkan minat belajar peserta pelatihan dengan berdampak positif terhadap hasil belajar. Sejalan dengan pernyataan Afryansih (2017), bahwa motivasi belajar memiliki hubungan yang positif terhadap hasil belajar.

Berdasarkan apa yang telah didapat dari uji ahli media \& materi serta uji coba lapangan, media video memang cocok digunakan dalam pembelajaran. Secara tidak langsung mampu memberikan motivasi lebih kepada peserta didik. Selain itu dari kondisi saat uji coba media juga mampu membuat peserta didik untuk fokus selama proses pembelajaran berlangsung. (Rahayu,Hadiarti, \& Kurniati, 2018) video pembelajaran yang layak dan efektif dapat dipakai sebagai media pembelajaran tambahan.

Media video tentang instalasi motor listrik 3 fasa salah satu media bantu yang bisa digunakan saat proses pembelajaran di dalam kelas. Kelebihan media video ini diantaranya bisa memanipulasi waktu dan ruang. Jadi video ini bisa diputar dimana saja dan kapan saja sesuai kebutuhan. Video dapat diulang untuk menambah kejelasan. Untuk menambah pemahaman video dapat diulang beberapa kali sesuai yang diinginkan untuk memahami secara maksimal. Pesan yang disampaikan cepat dan mudah diingat. Karena dalam media video lebih mengedepankan visual dan menjadikan pesan lebih mudah diserap karena lebih cepat dan mudah diingat (Siang, Hasan, \& Tamhir, 2019).

Media video mempunyai kelebihan memanipulasi waktu dan dapat memanipulasi ruang. Bisa juga mengembangkan imajinasi peserta didik karena di dalam video ini terdapat banyak tampilan yang menarik perhatian sehingga dapat mengembangkan imajinasi siswa. Hal ini sesuai pendapat yang dikemukakan oleh (Pramudito, 2013) yang dihasilkan, penggunaan media pembelajaran video akan membantu dan mempermudah proses pembelajaran tanpa memikirkan ruang dan waktu yang sangat terbatas.

Media pembelajaran adalah bagian dari pembelajaran dan juga perlu diintegrasikan dengan komponen pendukung lainnya. Semua komponen pembelajaran membutuhkan integrasi untuk 
kemudahan pengelolaan dan pemanfaatan. Para siswa akan mendapatkan kemudahan untuk mengakses materi dan media pembelajaran dari mana saja dan kapan saja (Surahman, 2019). Selain itu media pembelajaran yang baik harus dikembangkan secara adaptif sesuai dengan keragaman gaya belajar para pengguna (Surahman \& Alfindasari, 2017), (Surahman, Wedi, \& Soepriyanto, 2018).

\section{SIMPULAN}

Berlandaskan hasil validasi yang dilakukan oleh ahli materi, ahli media, dan responden (peserta pelatihan) pada tahap uji lapangan diperoleh hasil bahwa produk yang dikembangkan dinyatakan valid dan efektif. Berdasarkan persentase validasi ahli materi sebesar $89,2 \%$, ahli media $96,9 \%$, uji coba kelompok kecil sebesar 87,2\%, uji coba kelompok besar didapat skor $85 \%$ dan tes hasil belajar sebesar $86,5 \%$. Sesuai dengan kriteria yang telah ditentukan media video materi instalasi motor listrik 3 fasa di pelatihan instalasi tenaga listrik UPT Balai Latihan Kerja Surabaya dinyatakan valid. Sehingga media video ini bisa digunakan dalam proses belajar mengajar di kelas. Untuk dapat dimanfaatkan secara optimal maka para pengajar mata pelatihan instalasi motor listrik 3 fasa perlu menggunakan media yang telah dikembangkan.

\section{DAFTAR RUJUKAN}

Afryansih, N. (2017). Hubungan Motivasi Belajar dengan Hasil Belajar Siswa Geografi SMAN 5 Padang. Jurnal Spasial, 3(1). https://doi.org/10.22202/js.v3i1.1600

Allen, W. H. (1975). Intellectual abilities and instructional media design. AV Communication Review, 23(2), 139170.

Ardiansyah, R., Nrartha, I. M. A., \& Sukmadana, I. M. B. (2017). Perancangan Soft Starting Pada Motor Induksi Tiga Phase Menggunakan Mikrokontroller ATMEGA328. DIELENTRIKA, 2(2), 91-96.

Arends. (1997). Model-Model Pembelajaran Inovatif Berorientasi Konstruktivis. Jakarta: Prestasi Pustaka Publisher.

Arikunto, S. (2002). Dasar-Dasar Evaluasi Pendidikan (Edisi Revisi). Jakarta: Bumi Aksara.

Aulbur, W., CJ, A., \& Bigghe, R. (2016). Skill Development for Industry 4.0. In Roland Berger, BRICS Skill Development Working Group, India Section (pp. 1-50).

Azmy, A. (2015). Pengembangan Kompetensi Sumber Daya Manusia untuk Mencapai Career Ready Professional di Universitas Tanri Abeng. Binus Business Review, 6(2), 220. https://doi.org/10.21512/bbr.v6i2.971

Corley, M. A. (2012). TEAL Center Fact Sheet No. 6: Student-Centered Learning. TEAL (Teaching Excellence in Adult Literacy), (6), 1-3.

Hardianti, H., \& Asri, W. K. (2017). Keefektifan Penggunaan Media Video dalam Keterampilan Menulis Karangan Sederhana Bahasa Jerman Siswa Kelas XII IPA SMA Negeri 11 Makassar. Eralingua: Jurnal Pendidikan Bahasa Asing Dan Sastra, 1(2), 123-130. https://doi.org/10.26858/eralingua.v1i2.4408

Hartanti, E., Djatmika, E. T., \& Setyosari, P. (2017). Pengembangan mediavideo klip sebagai suplemen pembelajaran materi keberagaman budaya bangsaku. Jurnal Pendidikan: Teori, Penelitian, Dan Pengembangan, 2(6), 818-825.

Hesson, M., \& Shad, K. F. (2007). A Student-centered Learning Model. American Journal of Applied Sciences, 4(9), 628-636. https://doi.org/10.3844/ajassp.2007.628.636

Jatmika, H. M. (2005). Pemanfaatan Media Visual dalam Menunjang Pembelajaran Pendidikan Jasmani di Sekolah Dasar. Jurnal Pendidikan Jasmani Indonesia, 3(1), 89-99.

Johari, A., Hasan, S., \& Rakhman, M. (2016). Penerapan Media Video dan Animasi pada Materi Memvakum Dan Mengisi Refrigeran Terhadap Hasil Belajar Siswa. Journal of Mechanical Engineering Education, 1(1), 8. https://doi.org/10.17509/jmee.v1i1.3731

Kurniawan, D., Kuswandi, D., \& Husna, A. (2018). Pengembangan Media Video Pembelajaran Pada Mata Pelajaran Ipa Tentang Sifat Dan Perubahan Wujud Benda Kelas Iv Sdn Merjosari 5 Malang. JINOTEP (Jurnal Inovasi Dan Teknologi Pembelajaran) Kajian Dan Riset Dalam Teknologi Pembelajaran, 4(2), 119125. https://doi.org/10.17977/um031v4i22018p119

Mardiah, N. (2019). Peranan Positive Organization Behavior dalam Meningkatkan Kinerja untuk Menghadapi Era Revolusi Industri 4.0. Maqdis: Jurnal Kajian Ekonomi Islam, 4(2), 215. https://doi.org/10.15548/maqdis.v4i2.260

Mustika, R. (2015). Media Pembelajaran Sistem Audio untuk Pemberdayaan Pendidikan di Komunitas Masyarakat. Jurnal Masyarakat Telematika Dan Informasi, 6(1), 57-68. https://doi.org/http://dx.doi.org/10.17933/mti.v6i1.75

Neill, G. O., \& Mcmahon, T. (2005). Student-centred Learning: What for Students and Lecturers? Does It Mean. Emerging Issues in the Practice OfUniversity Learning and Teaching.

Nugrahani, R., \& Rupa, J. S. (2007). Media Pembelajaran Berbasis Visual Berbentuk Permainan Ular Tangga untuk Meningkatkan Kualitas Belajar Mengajar di Sekolah Dasar. Lembaran Ilmu Kependidikan, 36(1), 35 44. 
Nugroho, T. A. . (2015). Pengaruh Penggunaan Media Video Pembelajaran terhadap Keterampilan ProsesIPA dan Hasil Belajar IPA pada Siswa Kelas V SD Negeri Rejowinangun 1 Yogyakarta Tahun Ajaran 2014/2015. Universitas Negeri Yogyakarta.

Nur, M. (2005). Pembelajaran Kooperatif. Surabaya: UNESA Press.

Pradipta, P., Sutarto, S., \& Ghani, A. (2016). Media Video Kejadian Fisika di Lingkungan Disertai Besaran Fisis dalam Pembelajaran Fisika di SMA (Studi Pada Kelas X SMA Negeri 1 Muncar). Jurnal Pembelajaran Fisika, 4(4), 331-337-337.

Prasetyo, H., \& Sutopo, W. (2018). Industri 4.0: Telaah Klasifikasi Aspek dan Arah Perkembangan Riset. Jurnal Teknik Industri, 13(1), 17. https://doi.org/10.14710/jati.13.1.17-26

Purnomo, J., Yutmini, S., \& Anitah, S. (2014). Penggunaan Media Audio-Visual Pada Mata Pelajaran Ilmu Pengetahuan Alam Di Sekolah Menengah Pertama Negeri. Jurnal Teknologi Pendidikan Dan Pembelajaran, $2(2), 127-144$.

Rahayu,Hadiarti, \& Kurniati, 2018. (2018). Kata Kunci: Ekstraksi, Isolasi, Pengembangan Model 3-D, Video Pembelajaran. 6(1).

Sadiman, S. A. (2011). Media Pendidikan, Pengertian, Pengembangan, dan Pemanfaatannya. Jakarta: Raja Grafindo Persada.

Sanjaya, M. D. H., Adiarta, A., \& Santiyadnya, N. (2018). Pengembagan Media Pembelajaran Pemasangan Instalasi Listrik Dan Video Tutorial Instalasi Listrik Dalam Mata Kuliah Dasar-Dasar Instalasi Di Program. 7(2), 48-54.

Siang, J. ., Hasan, B., \& Tamhir. (2019). VideoDevelopment as Supporting Learning Media for Teachers at SMP Negeri 5 Tidore Islands. Proceeding of Community Development, 111-118.

Suparno. (1997). Filsafat Konstruktivisme dalam Pendidikan. Yogyakarta: Kanisius.

Surahman \& Alfindasari, 2017. (2017). Developing Adaptive Mobile Learning with the Principle of Coherence Mayer on Biology Subjects of High School to Support the Open and Distance Education. 128(Icet), 184190.

Surahman, E. (2019). Integrated Mobile Learning System (Imoles ) Sebagai Upaya Mewujudkan Masyarakat Pebelajar Unggul. 5(2), 50-56.

Surahman, E., Wedi, A., \& Soepriyanto, Y. (2018). Design of Peer Collaborative Authentic Assessment Model Based on Group Project Based Learning to Train Higher Order Thinking Skills of Students. 285(Icet), 2831.

Woottipong, K. (2014). Effect of Using Video Materials in the Teaching of Listening Skills for University Students. International Journal of Linguistics, 6(4), 200. https://doi.org/10.5296/ijl.v6i4.5870 